in fields of the order of hundreds of gauss and at temperatures as high as $500^{\circ} \mathrm{C}$.

This uniformity of magnetization combined with high magnetic stability of rocks ranging over such a wide geographical area and geological age evidently has some physical significance. Dr. Clegg considered a number of possible reasons for this preferential direction of the magnetic polarization and concluded tentatively that it might be due to a movement of Britain relative to the earth's geographical axis.

The most recent sediments measured are some post-glacial varved clays from Sweden. Dr. D. H. Griffiths (Geology Department, Birmingham) described measurements on two contemporaneous series of these clays from localities several miles apart on the Angerman River. The directions of magnetization show a regular variation suggestive of secular variation, and, over the 500-year period of overlap between the two series, good correlation of the directions is obtained, provided that corrections for the geological dip of the series are applied, amounting in one instance to $13^{\circ}$. Unfortunately, there is no supporting geological evidence for the validity of this correction. Dr. Griffiths also described measurements on recent varved-clay core samples obtained from the Angerman River delta with a non-magnetic Kullenberg core-sampler carrying a device for recording sample orientation. More than a hundred samples were measured covering the period A.D. 1400-1900, and it was therefore possible to compare magnetization directions with observatory records of the earth's field for this period. There was a rather large scatter in the measurements and average values of sets of samples had to be taken. The directions of the horizontal components of magnetization of the samples showed good agreement with the earth's field for corresponding periods, but inclinations were very variable and inconsistent. Correction for the small geological dip of the beds tended to improve correlation. These results were not altogether in agreement with measurements on the older varves, which were from the same general area, for in the older varves the evidence suggested that both declinations and inclinations were reliable.

A laboratory experiment showing how magnetization of sediments was acquired on deposition was described by Dr. R. F. King (Department of Geology, Birmingham). $\mathrm{H}_{\Theta}$ had redispersed some of the Swedish varved clay on which Dr. Griffiths's measurements were made, and had allowed it to settle slowly in the field of the earth. The direction of magnetization of this artificial sediment was not appreciably altered by the later application of a field in a different direction, although this was done while the clay was still under water and completely unconsolidated. Dr. King also described other experiments on resedimentation of clay, discussing in particular the discrepancy between the inclination of the remanence of the sediment and that of the applied field. This discrepancy has been noticed by other workers both in the laboratory and in the field, and is generally thought to be due to elongated or flattened magnetic particles tending to settle with their long axis or axes horizontal. Dr. Clegg, who had also noticed the effect, suggested that it could be due to rotation of the particles during the early stages of compaction. $\mathrm{He}$ described also an experiment in which a postdepositional field was applied to artificially deposited Keuper Marl. In contrast to the result of Dr. King's experiment; the direction of magnetization was found to rotate into that of the new field. The water content of his deposit was, however, considerably greater than that of the freshly deposited Swedish clay.

The various contributions to the meeting showed. that over the past year or two our knowledge of rock magnetism has greatly increased. Yet, despite the large number of observations that have been collected, it is obvious that many important problems will have to be solved before any general criteria of reliability can be established for rock magnetism measurements. For example, there is still some conflict of opinion on the question of reversed magnetization. 'There is also, as yet, no direct way of testing the stability of rock magnetization, though there is sometimes good indirect evidence of this. Finally, as model experiments are beginning to show, there is still much to be learned about the method by which the magnetic moment is acquired.

D. H. GRIFfithe

R. F. KING

1 Nagata, T., Nature, 172, 850 (1953).

${ }^{2}$ Hospers, J Nature, 168, 1111 (1951); Proc. Kon. Ned. Ak. Wet. $\mathrm{B}, 56,467$ (1953) ; $\mathrm{B}, 57,112(1954)$

3 Néel, L., Ann. Geophys., 7, 90 (1951).

4 Graham, J. W., J. Geophys. Res., 58, 243 (1953)

${ }^{5}$ Balsley, J. R., Trans. Amer. Geophys. Union, 35, 78 (1954)

' Gorter, E. W., and Schulkes, J. A., Phys. Rev., 90, 487 (1953).

' Fisher, R. A., Proc. Roy. Soc., A, 217, 295 (1953).

s Hospers, J., and Charlesworth, H. A. K., Mon. Not. Roy. Astro. Soc., Geophys. Supp. (in the press).

' Néel, L., Ann. Geophys., 5, 99 (1949).

${ }^{10}$ Runcorn, S. K., Trans. A mer. Geophys. Union, 35, 49 (1954).

\section{NEW LABORATORY OF THE MOTOR INDUSTRY RESEARCH ASSOCIATION}

\section{By DR. J. R. BRISTOW}

$T$

THE Motor Industry Research Association's new Laboratory, together with the Proving Ground, was officially opened on May 21 by the Minister of Transport, the Right Hon. Alan Lennox Boyd, in the presence of distinguished guests, representing the motor industry, universities and Government departments, and some twelve hundred visitors.

The Laboratory stands on an 11-acre site in the angle formed by the Watling Street $(A 5)$, and a private road leading to the Association's Proving Ground, at Lindley, near Nuneaton. The Laboratory, which has a floor area of about 30,000 sq. ft., together with other buildings (canteen, garages and workshop) having a total floor area of about 10,000 sq. ft., occupies about half the site, thus providing room for considerable future expansion.

The lay-out of the main building is based on a wide $L$-shaped corridor with offices, conference room, drawing office, entrance hall, etc., on the 'outside' of the corridor forming a main frontage, about $300 \mathrm{ft}$. long, parallel to the Watling Street, and a subsidiary frontage, about $125 \mathrm{ft}$., parallel to the private road to the Proving Ground. The separate research laboratories electronics, metallurgical, general engineering, engine, machine shop and stores-consist of open wings (with windows along both sides and roof lights) leading off at right angles from the longest corridor. There are no small separate rooms for research purposes, a small number of large open floor spaces being more suited to the Association's needs than a large number of small restricted floor 


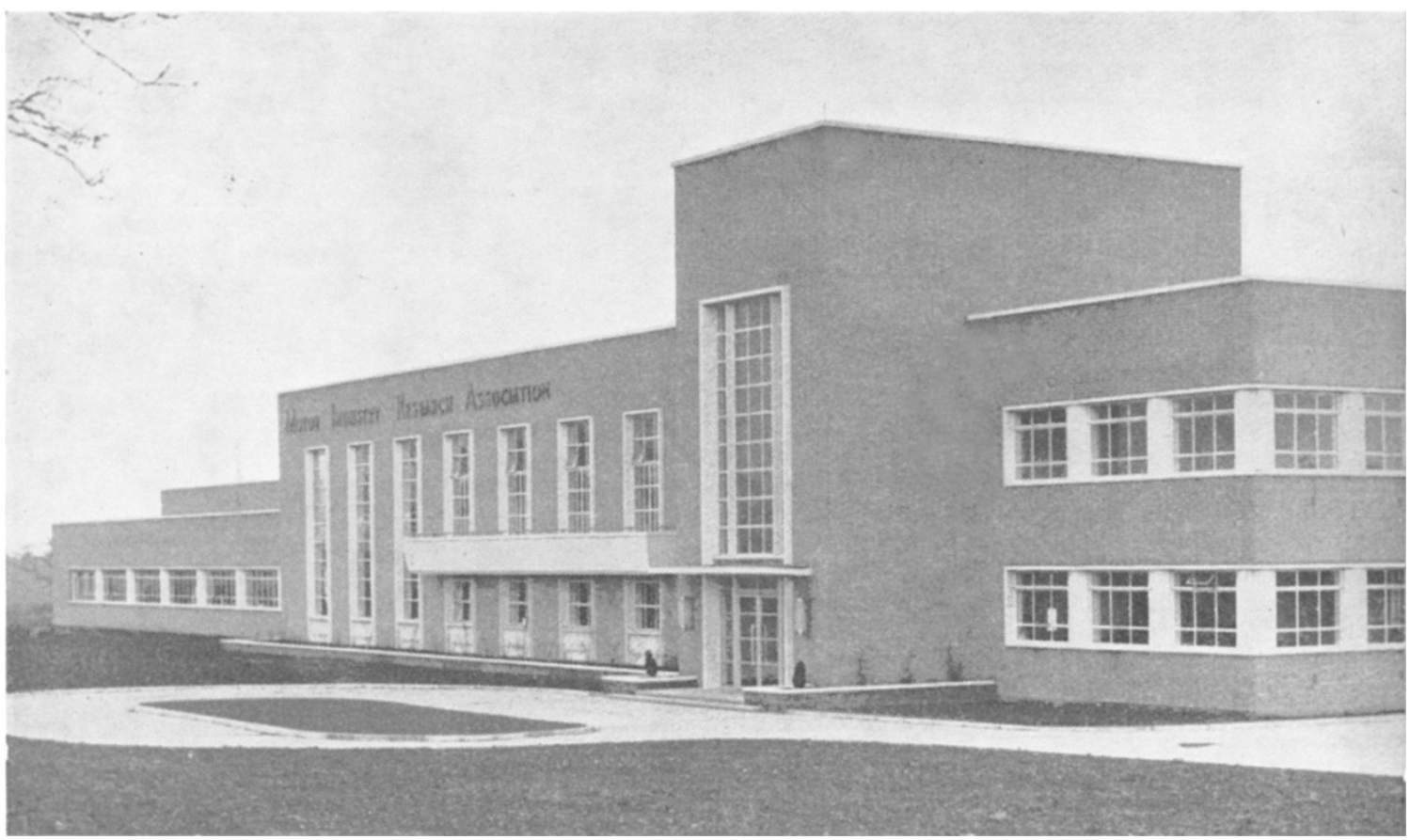

New Laboratory of the Motor Industry Research Association

areas. The building is of steel-frame brick-panel construction. That part of the structure consisting of offices, library, etc., is two-storied, the first floor and roof being of hollow-tile construction with spaceheating by low-temperature ceiling panels. All the research floor area is at ground-floor level only, with steel deck roofing and high-temperature radiators for space-heating. (The boilers for space-heating are oil-fired and automatic.) Lighting is by tungsten lamps throughout the building except in special cases, for example, the drawing office and measuring room.

The Electronics Laboratory is $50 \mathrm{ft} . \times 30 \mathrm{ft}$.; a wall bench and an island bench give working space for nine people and are well supplied with a.c. and d.c. points; there is a stabilized high-tension power supply to each work space. Two other wall benches are set aside for metal working and for calibrating instruments against laboratory standards. The laboratory is well equipped with oscillators, valve voltmeters, oscillographs, etc. The purpose of the Electronics Section is to design and construct special equipment for the Association's work in general, and to undertake the study of problems in which instrumentation is the major feature, or which are 'physical' rather than engineering in nature, for example, the study of noise in vehicles. In connexion with this latter, there is attached to the Electronics Laboratory a 'noise-room', large enough to accommodate a motorcar, in which all internal surfaces are treated with wedges of noise-absorbent material giving 'free-field' conditions over a wide frequency-range. Examples of the type of equipment developed in the section are torque-meters for measuring steering torque and axle torque, accelerometers, dynamic strain-recording equipment suitable for use on the roads with wireresistance strain-gauges, and noise-recording equipment.

The Metallurgical and Chemical Laboratory contains two island benches (one for assay and one for metallography), wall benches, fume cupboards and temperature-controlled furnaces, polishing machines, etc. There is also a balance room, and a small dark room situated conveniently next to a Vickers projection metallurgical microscope.

The General Mechanical Engineering Laboratory is a large open space $100 \mathrm{ft} . \times 58 \mathrm{ft}$. ; in it all the experimental work requiring mechanical 'rigs' is carried out, save that involving the power-unit (see later). A large section of the Association's work involves the study of fatigue strength of materials and components, and fatigue machines at present housed in this Laboratory are for bending and torsional fatigue of crankshafts (4), small Wöhler machines (2), hydraulic pulsators for fatigue testing of gear teeth (2), and power circulating gear machines (2) for the study of 'pitting' (surface fatigue). Generally it is desirable to carry out measurements using specimens in the shape of the actual com. ponents, particularly in the case of castings, and it is even necessary in investigations into the effect of materials and methods of manufacture to use specimens of component form. Hence the machines are predominantly for fatiguing components, rather than of the type which take laboratory specimens. Other apparatus in this Laboratory concerns the operation of brakes. A machine for studying 'fading' of brakes (that is, changes of coefficient of friction with temperature) is essentially a rotating drum, the temperature of which can be controlled, against which a piece of lining material is pressed in such a way as to give no 'servo' action. Apparatus for turning a road wheel continuously with the brakes applied and with means of recording brake pressure, friction torque and temperature is for the study of the mechanism of brake squeak. Within this Laboratory is a measuring room, housing measuring instruments and standards, Vickers hardness machine, involute tester and surface roughness measuring equipment, and also a dark room containing an N.P.L. type profile projector. 
The Engine Laboratory (88 ft. $\times 30 \mathrm{ft}$.) has eight. fully equipped engine test bays. The walls, ceilings and partitions of the Laboratory are treated with sound-absorbing material; and the walls are not directly connected with the rest of the building, so as to reduce transmission of noise and vibration. Engine stands and dynamometers are mounted together on large concrete beds which are cushioned on rubber to reduce vibration transmitted to the floor. Three beds have electric dynamometers and the other five water brakes. Fuel lines (diesel and petrol) run to each bed, together with water and electric power. As well as investigations concerning the operation of the power-unit as such, any work involving the running of an engine under power is carried out in this Laboratory; for example, the measurement of loads in crankshafts (in progress at the time of writing) using wire-resistance straingauges attached to the shaft.

The workshop, which is fully equipped to undertake all the Association's needs for special apparatus, instruments and test specimens, is $100 \mathrm{ft} . \times 29 \mathrm{ft}$.; and there is a general stores of similar size. There is a small drawing office $(50 \mathrm{ft} . \times 20 \mathrm{ft}$.) and photographic rooms $(40 \mathrm{ft}$. $\times 22 \mathrm{ft}$. $)$. The conference room, which is equipped for the projection of $35-\mathrm{mm}$. sound films and lantern slides from a projection room outside it, is $46 \mathrm{ft} . \times 22 \mathrm{ft}$. In addition to the library (40 ft. $\times 22 \mathrm{ft}$.), in which only bound volumes are kept, there is a library store $(46 \mathrm{ft} . \times 22 \mathrm{ft}$.) for unbound literature. Through the Information Section about 7,000 loans of technical literature are made each year, and for documents in great demand a photo-copying service is operated.

Obviously, much of the Association's research. work, such as that connected with stresses in vehicle structures and noise in vehicles, has to be carried out on the road, and the Proving Ground provides private roads for this purpose. In addition, the Proving Ground has been equipped with features which make it a testing ground on which manufacturers can prove their vehicles, as well as using it for development and research work which would otherwise (and less conveniently) have to be carried out on public roads. The Proving Ground covers nearly 650 acres, with $12 \frac{1}{2}$ miles of track and special road surfaces ; features include a banked circuit on which high speeds can be continuously maintained; a pavé track which is used for accelerated endurance tests on complete vehicles; a corrugated track which reproduces the well-known non-metalled 'washboard' roads of tropical and sub-tropical countries; a "water splash'; a 'dust tunnel' for studying dust entry, etc.

\section{NEW BUILDINGS FOR THE UNIVERSITY OF GLASGOW}

$\mathrm{T}$ a ceremony held in the Bute Hall of the
University of Glasgow on March 19, the Right
Hon. James Stuart, Secretary of State for Scotland,
inaugurated the new buildings which have been
erected for the University since the conclusion of the
Second World War. Some of these buildings are not
yet complete, but they are all in use. There are six
entirely new buildings, ranging from the final block
of the new Chemistry Institute, with a floor area of
more. than 80,000 sq. ft. and costing more than
$£ 500,000$, to a small extension of the Zoology Depart- ment, with a floor area of some 5,600 sq. ft. and built at a cost of $£ 24,500$. In addition, there have been major works of reconstruction and adaptation which have provided increased accommodation and more modern facilities for the University Offices and for the Departments of Bacteriology, Biochemistry, Botany, Genetics, Mathematics and Pharmacology. Also, a factory has been purchased and is being converted into a research block for mechanical engineering. In all, these new buildings and reconstructions have cost about $£ 2$ million, of which more than 90 per cent has been provided from public funds.

The most mundane of these projects is the new boiler-house (architects : Messrs. Gillespie, Kidd and Coia). This had become necessary not only because the old boilers were on the verge of complete breakdown, but also because they were quite unable to meet the demands of the new buildings in course of construction on Gilmorehill. Construction of the new boiler-house involved a difficult and costly excavation of the hillside. The northern side of the roof is on a level with the adjoining roadway and on the roof itself are two excellent tennis courts. Three Penman's economic boilers have been installed, each of which can give 12,500 lb. of steam per hour. The fuel store takes 560 tons of coal, which is fed to the stoker hoppers by coal elevators. The only man-handling needed is in raking out the ash, and the efficient operation of the plant is assisted by the usual automatic recorders. Considerable economy in fuel has resulted from this installation.

The new extension for the Department of Natural Philosophy (architects: Messrs. Basil Spence and Partners) is more advanced in its architectural conception than any other of the University buildings. It provides increased and modern facilities for research in both experimental and theoretical physics. The rectangular main block, consisting of four floors and a basement, each with a central corridor, has at the east end a $300-\mathrm{MeV}$. synchrotron with its associated rooms. In the main block are about twenty research rooms, mainly used for small-scale researches in nuclear physics. The unit size is $16 \mathrm{ft}$. by $16 \mathrm{ft}$., but a few rooms consist of one and a half such units and a few of two units. Techniques rooms, photographic dark-rooms, rooms for mathematical physicists, private rooms, a museum and a library complete the main block.

The synchrotron end of the building consists of a main hall, $54 \mathrm{ft}$. by $26 \mathrm{ft}$., for general machineassembly purposes, this hall containing a 50-ton crane with which the whole of the top section of the synchrotron magnet can be lifted. A large part of the floor of this hall consists of a sliding slab of barytes concrete $2 \mathrm{ft}$. thick and weighing 120 tons which, when closed, forms the roof of the chamber in which the synchrotron magnet is housed below ground-level. The rest of the building is thus screened effectively from the radiation and noise of the synchrotron. The beam of high-energy radiation passes through a door in the synchrotron chamber into a beam room, $33 \mathrm{ft}$. by $16 \mathrm{ft}$., also below groundlevel. Immediately above this are two research rooms with slots in the floor, so that the apparatus in the beam room may be watched and manipulated from a safely screened position.

The main synchrotron magnet weighs 120 tons, of which 70 tons is constructed of laminations $0.014 \mathrm{in}$. in thickness. The diameter of the circular orbit of the electrons during acceleration is $2 \frac{1}{2} \mathrm{~m}$. The magnet is excited five times a second with a 